\section{Sulive}

Aralık 2021/Sayı: 11

December 2021/Issue: 11

\title{
Aslî Günah Kavramını Mevlânâ'nın Günah Tasavvuru İle Birlikte Yorumlamak
}

Interpreting the Concept of the Original Sin with Sin Concept of Mawlana

Dr. Öğr. Üyesi

\section{Abdullah KUŞLU}

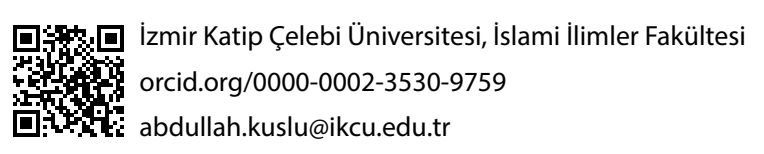




\section{Sufinge}

230

\section{$\ddot{O} z$}

Hz. Âdem'in yasak ağaca yaklaşması ve cennetten çıkarılması insanoğlunun başlangıç hikâyesidir. Dolayısıyla Allah-insan ilişkisi bağlamında bu konu semâvî dinlerin ortak konusudur. Her ne kadar semâvî dinler bu meseleyi kendi inanç ilkeleri açısından farklı perspektiflerden ele alsa da bu konuda en çok tartışmanın Hristiyan düşüncesinde olduğu öngörülebilir. Pavlus, Âdem Peygamber'in yasak ağaca yaklaşmasını ilk günah olarak yorumlayarak fikirlerini Hristiyan düşüncesinin merkezine taşımış ve onun fikirleri sonraki zamanlarda daha geniş bir şekilde Hristiyan teologlar tarafından tartışlarak özellikle Augustinus tarafından sistematize edilmiştir. Pavlus'un düşüncesine göre Âdem Peygamber'in kendi iradesiyle yasak ağaca yaklaşmasından dolayı insanın kötülüğü tercih edebilme potansiyeli (irade) ortaya çımış ve insan kötülükle tanışmışıı. Bundan böyle bütün insanların üzerinde bu günahın izleri görülecektir, çünkü Âdem Peygamber hataya düştüğünde aslında onun sulbünde bütün insanlık günaha düşmüştür.

Aslî günah teorisi Hristiyan düşüncesinin sadece Tanrı ya da insan tasavvurunu değil dünya hayatı ile ilgili tasavvurunu da etkilemiştir. Bu bağlamda günahın bir sonucu olarak insan için bu dünya hayatı bir sürgün yeri, bir cezalandırlma mekânıdır ve insan bu dünyaya atılmıştır. Mevlânâ'nın eserlerinde de dünya hayatının, mahpus, sürgün yeri, dar bir ova, Yusuf'un zindanı, ısınmı hamam gibi metaforlarla anıldığını görmekteyiz. Sözkonusu makale Âdem peygamber'in cennetten dünya hayatına gönderilmesinden ve dünya hayatıyla ilgili bazı metaforik anlatımlardan hareketle Mevlânâ'nın günah tasavvurunu izah etmektedir. Makale, Mevlânânın dünya hayatıyla ilgili bazı beyitlerinin Pavlus'un karamsar bir dünya tasavvuru ve günah teorisiyle örtüşüp örtüşmediğini anlamayı amaçlamaktadır. Aynı zamanda Pavlus ve Mevlânâ’dan hareketle Hristiyan ve İslâm düşüncesinin insan, günah ve dünya hayatıyla ilgili tasavvurları hakkında bütüncül bir perspektif ortaya koymayı hedeflemektedir.

Anahtar Kelimeler: Tasavvuf, Mevlânâ, Âdem, Pavlus, Aslî günah

\section{Abstract}

Approach of Adam to the forbidden tree and his expulsion from the Heaven is the origin story of mankind. Therefore, in the context of the relationship between God and humans, this issue is the common matter of the Abrahamic religions. Although Abrahamic religions handle this issue from their own perspective with their own belief principles, it can be seen that the debate on this topic is mainly in Christian thought. Apostle Paul put his ideas at the center of Christian's thought by interpreting the Adam's approach to the forbidden tree as the original sin. His ideas were discussed more by Christian theologians in later times and systematized especially by St. Augustine. According to Paul's idea, when Adam approached the forbidden tree with his own will, the potential of human choice of evil has emerged and mankind met sin. Since then, traces of this sin are seen on all human beings because when Adam fell into a mistake, indeed, all humanity fell into the sin of Adam.

The Original Sin Theory influenced Christian thought not only by the aspect of God or humans concept but also the view of world life. In this context, this worldly life in which human beings have been thrown is a place of exile and punishment as a compensation of sin. In works of Mawlana, we see that the life of the world is mentioned with metaphors such as prison, $a$ foreign place, a narrow plain, Joseph's dungeon, and heated bath. This article analyzes Mawlana's concept of sin, based on the expulsion of the Adam from the Heaven and some metaphorical expressions about earthly life. It also discusses the similarity of his thoughts regarding his view of the world and the sending of human to the world with the original sin theory. The article aims to understand whether some of Mawlana's couplets about the worldly life overlap with Paul's pessimistic conception of the world and his theory of sin. At the same time, it tries to present a holistic perspective on the conceptions of Christian and Islamic thought about human, sin and worldly life, based on Paul and Mawlana.

Keywords: Sufism, Mawlānā, Adam, Paul the Apostle, Original Sin 


\section{Giriş}

†nsanlığın atası olarak Hz.Âdem’in yaratılması, hataya düşmesi, cennetten çıkarılması insanın hem yaratıcı ile olan ilişkisi hem insanın günahı tercih etme noktasında irade hürriyeti açısından bütün semâvi dinlerin konusu olmuş ve sadece İslâm düşüncesinde değil Yahudi ve Hristiyan düşüncesinde de çokca tartışlagelmiştir. Bu meyanda Âdem Peygamber'in hatası üzerinden insanın iradesi ve günaha düşmesi, dünya hayatının keyfiyyeti, dünyanın zemmi ve methi, semavî dinlerin ortak konusu olagelmiştir. Öte yandan semâvî dinlerin insanı bilmek/anlamak düzleminde yaratıcı-insan ilişkisine dair yorumları bazen birbiriyle örtüşmekte bazen de farklılıklar arzetmektedir. ${ }^{1}$

Hz. Âdem'in cennetten çıkarılması sözkonusu olunca öncelikle semâvî dinlerden Hristiyanlık ve Hristiyan düşüncesinde mevcut aslî günah teorisi karşımıza çıkmaktadır. Aslî günah teorisi sadece Pavlus'un (ö. 67) yaşadığı dönemde değil sonraki zamanlarda da tartışılmış ve günümüze kadar güncelliğini korumuştur. Bununla birlikte aslî günah denilince ilk akla gelen Pavlus olsa da bu teoriyi daha derinlikli ve detaylı bir şekilde tartışan ve doktrinleştiren Hristiyan teolog Augustinus'dur (ö. 430). ${ }^{2}$

Hristiyan düşüncesinde (ki bu ifadeyle Pavlus ve sonraki dönemlerde Augustinus ve onları takip eden teologlar kastedilmektedir) aslî günah denilince sadece bir defaya mahsus bir eylemden değil bütün insanlığ 1 etkileyen bir meseleden bahsedilmektedir. Âdem Peygamber'in hatası ve cennetten çıkarılması Hristiyan düşüncesinin sadece günah konusunda değil insan ve dünya tasavvuru hakkında da bilgi verir. Çünkü aslî günah, insanın fitratında varolan iyiliğin örtülmesi ve neticede de insanın günahı terkederek iyiliği tercih etme kabiliyetinin zaafa uğramasıyla sonuçlanan bir süreçtir. ${ }^{3}$

Bununla birlikte bir peygamber olarak Hz. Âdem'in eylemi ve neticede cennetten çıkarılması hususu tefsir, kelâm ve İslâm düşüncesinin kaynaklarının önemli tartışma konularından biridir. Bu bağlamda Hz. Âdem'in eyleminin zelle yahut günah olarak adlandırılması, onun yasak

\footnotetext{
1 Hakan Uğur, Tevrat'in Kur'an’a Arzı: Kur'an’ın Tevratta Tasdik Ettiği Konular (Bursa: Emin Yayınlar1, 2011), 189-191.

2 Muhammet Tarakçı, “St. Thomas Aquinas’a Göre Aslî Günah”, Uludağ Üniversitesi İlahiyat Fakültesi Dergisi 15/1 (2006), 309.

3 Tarakçı, "St. Thomas Aquinas’a Göre Aslî Günah”, 310.
} 
ağaca yaklaşmasının nasıl yorumlanması gerektiği, yasak ağacın ne olduğu konuları klasik dönem sünnî kelâm kaynaklarında tartışılagelmiş peygamberlerin ismet sıfat cihetinden zelle olarak isimlendirilmiştir. Konunun genişliği ve bağlamından kopmaması amacıyla öncelikle aslî günah ile ilgili kaynaklara başvurulduktan sonra Mevlânâ’nın (ö. 1273) Hz. Âdem'in cennetten çıkarılmasını ve insanın eylemi olarak günah kavramını nasıl yorumladığı cihetinden daha çok Mesnevî'den istifade edilmiştir. Kelâm ve tefsir kaynaklarına makalede yüzeysel olarak temas edilmiş konunun çerçevesi Mevlânâ’nın fikirleri ekseninde tasavvufî düşünce bağlamında incelenmiştir.

Makalede Mevlânâ’nın günah kavramının Pavlus'un aslî günah kavramıyla birlikte yorumlanmasının/irdelenmesinin gerekçesi izah gerektirmektedir. İlk olarak Hristiyan düşüncesindeki aslî günah kavramı sadece Âdem Peygamber'in günahı olarak görülmemekte Hristiyanlığın insan ve dünya tasavvuru konusunda da belirleyici olmaktadır. Bu cihetten bakıldığında Hristiyan düşüncesinde insanın aslî günahın tesirinde kalmasıyla dünya hayatı sürgün ve ceza yeridir. Dünya hayatıyla ilgili anlatımlarda Mevlânâ'nın da dünya hayatını ney metaforunda olduğu üzere bazen gurbet, ${ }^{4} b a z e n$ zindan, ${ }^{5} b a z e n ~ d e ~ Y u s u f ' u n ~ k u y u s u{ }^{3}$ gibi metaforlarla tasvir ettiğini söyleyebiliriz. Aslî günahı savunan teologlar dünyanın sürgün yeri olduğunu ifade ederken Âdem Peygamber'in kendi iradesiyle iyi olmaktan vazgeçtiğini ve onun bu tercihinden dolayı artık bütün insanların bu günahla doğduğunu vurgulamaktaydı. Dolayısıyla bu günah bir yandan Âdem Peygamber'in düşmesine sebeb olurken bir yandan da iradenin tahrip olmasına yol açmıştır. Âdem Peygamber'in cennetten çıkarılması Hristiyan düşüncesinde her ne kadar aslî günahla ilintili olarak tartışılmışsa da İslam düşüncesinin de temel tartı̧̧malarından biridir ve Mevlânâ da Mesnevî̀ sinde Âdem Peygamber'in cennetten çıkarılmasını bazen Allahinsan ilişkisi, bazen insanın dünyaya gönderilmesi bazen de insanın iradesiyle iyiyi ve kötüyü tercih edebilmesi cihetinden konu edinmiştir. Bu minvalde Mevlânầnın dünya tasavvuru ile Hristiyan düşüncesinde aslî günah teorisini ortaya koyan Pavlus'un dünya tasavvuru arasında örtüşen ya da ayrılan noktalar nelerdir? Mevlânâ’nın dünya hayatı, insan ve

4 Mevlânâ, Mesnevî̀-i Manevî̀ (Konya: Konya Kültür A.Ş., 1384), 1/1-18.

5 Mevlânâ, Mesnevî̀-i Manevî, 1/983.

6 Mevlânâ, Mesnevî̀-i Manevî, 4/ 672. 
günahla ilgili metaforlarının ne anlama geldiğini aslî günah kavramıyla kıyaslayarak daha geniş bir perspektiften okuyabilir miyiz? Mevlânâ'nın insan, dünya hayatı ve insanın eylemi olarak günah kavramına yüklediği anlam; aslî günah kavramıyla birlikte ele alındığında Pavlus ve Mevlânâ bağlamında Hristiyan ve İslâm düşüncesinin insan, insanın eylemi olarak günah ve dünya hayatıyla ilgili tasavvurları hakkında genel de olsa bütüncül bir perspektif ortaya koyar mı? Bu sorular bağlamında makale bir veçhesiyle Hristiyan düşüncenin temel problemlerinden birisi olan aslî günah kavramını ve aslî günah düşüncesinin yol açtı̆̆ı insan ve dünya tasavvurunu bir veçhesiyle de Mevlânâ’nın perspektifinden günah ve günahın Allah-insan ilişkisi açısından nasıl yorumlandığını konu edinmektedir.

Hritiyan düşüncesinin aslî günah doktrininden bahsedildiğinde Şinasi Gündüz’ün Pavlus: Hristiyanlğgn Mimar ${ }^{7} 1$ isimli eseri konu hakkında kapsamlı çalışmalardan birisidir. Fuat Aydın'ın Pavlus Hristiyanlı̆̆ına Giriş̧ ${ }^{8}$ isimli eseri de makalede müstefid olunan önemli eserlerden biridir. Aslî günah konusunda kapsamlı çalışmalardan biri de Espensberger'in Die Elemente der Erbsünde nach Augustinus und der Frühscholastik, -Augustinus ve Erken Dönem Skolastik Düşünce'ye Göre Aslî Günahın Unsurlarl- isimli eseridir ki bu eserden de makale boyunca istifade edilmiştir. ${ }^{9}$

Bilal Doğan Hristiyanlık'ta Aslî Günah Doktrini ${ }^{10}$ isimli doktora çalı̧̧masında aslî günah doktrininin teolojik temellerini konu edinmekle yetinmemekte aslî günah teorisini reddeden Pelagius'un (ö. 420) fikirlerini ve aslî günaha karşı çıkmasındaki temel argümanları da irdelemektedir. Cengiz Batuk'un Hristiyanlı̆̆ın Aslî Günah Doktrini Bağlamında Mitoloji ve Tarihsellik ${ }^{11}$ isimli doktora çalışması aslî günah doktrininin Hristiyan düşüncesindeki tarihsel seyrini Augustinus ve Pelagius'un düşünceleri bağlamında ayrıntılı olarak ele almaktadır. Modern dönemlerde aslî günah doktrininin tekabül ettiği felsefik teolojik yorumları ihtiva etmesi ve

\footnotetext{
7 Şinasi Gündüz, Pavlus: Hristiyanlığın Mimarı (Ankara: Ankara Okulu, 2001), 211. 8 Fuat Aydın, Pavlus Hristiyanlı̆̆ına Giriş (Ankara: Eskiyeni Yayınları, 2011), 246-247.

9 Joh. Nep. Espensberger, Die Elemente der Erbsünde nach Augustinus und der Frühscholastik, ed. Albert Ehrhard - Johnann Peter Kirsch (Mainz: Verlag von Kirchheim, 1905), 92. 10 Bilal Doğan, Hristiyanlıkta Aslî Günah Doktrini (Bursa: Uludağ Üniversitesi, Sosyal Bilimler Enstitüsü, Felsefe ve Din Bilimleri Anabilim Dalı, Dinler Tarihi Bilim Dalı, 2008).

11 Cengiz Batuk, Hristiyanlı̆̆ın Aslî Günah Doktrini Bağlamında Mitoloji ve Tarihsellik (Samsun: Ondokuz Mayıs Üniversitesi, Sosyal Bilimler Enstitüsü, Felsefe ve Din Bilimleri Ana Bilim Dalı, Doktora Tezi, 2006).
} 
mitoloji ile gerçeklik arasındaki geçişkenliğin aslî günah doktrini bağlamında analiz edilmesi konunun farklı perspektiflerden okunabileceğini göstermektedir. Fuat Aydın, Pavlus ve Din Anlayışının Yansımaları isimli tezinde ${ }^{12}$ Pavlus'un ahlâk anlayışının Yahudi ve Helenistik arka planını da irdelerken Pavlus eskatolojisinin ana konularına da yer vermektedir. Eduart Caka'nın Bir Mistik Olarak Pavlus ${ }^{13}$ isimli doktora çalışması Pavlus mistisizminin kökenini irdelemekte ve Pavlus'un fikirlerinin Hristiyan mistisizminin teșekkülündeki etkisini ve önemini analiz etmektedir.

Aslî günah teorisini ve Hristiyan teolojisinde günahın neticesinde insanın dünyaya gönderilmesini bütüncül bir perspektiften aktaran eserlerden birisi de Katolik kilisesi tarafından Hristiyan düşüncesinin temel kâidelerini konu edinen ve Türkçe'ye Katolik Kilisesi Din ve Ahlak İlkeleri ismiyle tercüme edilmiş olan eserdir. Eserde aslî günah doktrininin temel çerçevesi belirlenerek aslî günahla irtibatlı meselelere değinilmekte ve aslî günahın neticesinde insanın dünyaya gönderilmesi, insanın fitrî olarak kötülüğün etkisinden kurtulamaması, İsa Mesih’in insanlığı kurtarmak için feda edilmesi, vaftiz âyini gibi konular genişçe yer almaktadır. ${ }^{14}$

Makalede aslî günah doktrininin Mevlânâ’nın günah tasavvuruyla birlikte yorumlanmasının sebebi Mevlânâ'nın dünya hayatı hakkında bazı ifadelerinin ve Âdem Peygamber'in cennetten çıkarılmasıyla ilgili metaforik anlatımının Hristiyan düşüncesinde aslî günah kavramını anımsatması olarak ifade edilmişti. Diğer yandan Mevlânâ’nın dünya hayatıyla ilgili tasvirlerinin bazen iyimser bazen kötümser bazen nötr bir anlam çerçevesinde ilerlediği bilinmektedir. Ancak makalede Pavlus ve Mevlânâ'dan hareketle Hz. Âdem'in cennetten çıkarılması, insanın dünyaya gönderilmesi ve Allah-insan ilişkisi öncelendiği için Mevlânâ’nın dünya hayatıyla ilgili bütün metaforik anlatımlarına yer verilmemekte Hristiyan düşüncesinde mevcut aslî günah kavramına ve Mevlânâ’nın günah tasavvuruna odaklanılmaktadır.

12 Fuat Aydın, Pavlus ve Din Anlayışının Yansımaları (İstanbul: Marmara Üniversitesi, Sosyal Bilimler Enstitüsü, Felsefe ve Din Bilimleri Anabilim Dalı, Dinler Tarihi Bilim Dalı, Doktora Tezi, 2000).

13 Eduart Caka, Bir Mistik Olarak Pavlus (Bursa: Uludağ Üniversitesi, Sosyal Bilimler Enstitüsü, Doktora Tezi, 2014).

14 Katolik Kilisesi Din ve Ahlak İlkeleri, çev. Dominik Pamir (İstanbul: Yaylacık Matbaacılık Ltd. Şti., 2000). 


\section{Hristiyan Düşüncesinde Aslî Günah Teorisi ve Aslî Günahın İnsan Fitratına Etkisi}

Aslî günah kavramı insanların ilk atası olması sebebiyle Âdem'in işlediği günahın -ki bu kavram Hristiyan metinlerin tanımlaması cihetindendir- sonraki nesillere geçmesini ifade etmektedir ve Hıristiyanlığ diğer semavî dinlerden ayıran temel özelliklerden biridir. Her ne kadar Pavlus'un düşünceleri önemli bir role sahip olsa da aslî günah kavramı Augustinus tarafından doktrinleştirilmiştir. ${ }^{15} \mathrm{Bu}$ doktrine göre Âdem'in işlediği suç ile birlikte insanoğlu günahla tanışmış ve onun günahı da diğer insanlara miras olarak devretmiştir. ${ }^{16}$ Dolayısıyla insan kendine verilen özgürlügü kötüye kullanarak Tanrı'nın buyruğuna karşı gelmiştir ve sonraları insan tarafından işlenen her günah bir itaatsizlik ve Tanrı'nın iyiliğine karşı güvensizliğin göstergesidir. İnsan gerçekte kendini ve kendi özgürlüğünü Tanrı'ya yeğlemiş Tanrı gibi olmak istemiştir. Oysa Tanrı insanı kendi sûretinde yaratarak dost edinmiştir ve yasak ağaç insanın simgesel olarak saygı ve güven içerisinde özgür iradesiyle aşmaması gereken sınırı belirlemektedir. ${ }^{17}$

Pavlus ile birlikte sonraki dönemlerde Âdem'in günaha düşüşü ile insanlığın bu günahtan etkilenmesinin nasıl olabileceği meselesi bir problem olarak hep tartışılagelmiştir. Bu açıdan Âdem Peygamber'in hataya düşmesi ile insanoğlunun günah işlemesi arasındaki bağ şu şekilde açılanmaktadır. Gerçekte Âdem günah işlediğinde (bütün herkesin) doğmamış çocukların kendi iradeleriyle günah işlediği kolayca söylenemez ancak buna rağmen günah âdemoğullarının da tümden yabancı olduğu bir durum olarak ele alınmamalıdır. Herkes Âdem'de günaha düşmüştür çünkü herkes onun sülbündendir. Bu yüzden Âdem günaha düştüğünde bütün insan soyu onda günaha düşmüştür. ${ }^{18}$

Aslî günahla ilgili bu düşünme biçimi aslî günah probleminin ortadan kalkmasına değil aksine ortaya çıkan sorunun büyümesine ve yeni soruların da bu öğretiye eklenmesine yol açmıştır. Örneğin doğmamış bir çocuğun Âdem'in günahını devralmasının mümkün olup olmayacağ̣ sorusu büyük bir problem olarak temel tartışma konularından biri

\footnotetext{
15 Tarakçı, “St. Thomas Aquinas’a Göre Aslî Günah”, 309.

16 Espensberger, Die Elemente der Erbsünde nach Augustinus und der Frühscholastik, 92.

17 Katolik Kilisesi Din ve Ahlak İlkeleri, 107-108.

18 Tarakçı, “St. Thomas Aquinas'a Göre Aslî Günah”, 310.
} 
olmuştur ve bazı Hristiyan teologlar şu soruyu sormaktan geri durmamıştır: Doğmamış bir çocuğun günaha düşmesi mümkün müdür yahut kabul edilebilir mi? Çünkü Âdem kendi iradesiyle günah işlemiştir ve doğmamış bir çocuk için sözkonusu günah henüz gerçekleşmemiştir. ${ }^{19}$

Diğer yandan bazı Hristiyan teologlar aslî günah kavramını Âdem Peygamber'in dürüst olmaktan kendi iradesiyle vazgeçtiği tezi üzerinden açıklamayı denemektedirler. Âdem Peygamber dürüstlüğ̈ü kendi iradesiyle terketti ve bu yüzden onların yorumlarına göre artık özgür iradeyle birlikte aslî günah kavramının varlığg da inkâr edilemez. Bu açıdan bakıldığında her bir kimse başlangıçta bu dürüst olmamayı miras alıyor, her bir kimse bu fitrat üzere doğuyor ve böylece cennetteki günah kaynağında kalmadan bütün her yere yayılıyor. ${ }^{20}$

Bu düşünme biçimi Hristiyan teolojide daha da genişleyerek insanın kötü eylemlerinin, dünya hayatının ve dahi ölümün bir sebebi olarak yorumlanabilmektedir. Her ne kadar doğumumuz bir kadından olsa da gerçekte bizim nefes almaya başladığımız hayat günahın dünyasıdır ve her bir kimse (bu günah yüzünden)kısa yaşamaktadır. Günahtan dolayı her bir kimse “Âdem gibi Tanrı'nın kelimelerine/kelâmına sağır, Allah'1 bilmek mevzuunda kör ve Tanrı reddettiği için topaldır”21 ve aynı zamanda doğası gereği herkes günahın neticesinde dünyaya egemen ölümün kısırdöngüsü içindedir. ${ }^{22}$

Bu tartışmalar neticesinde Âdem'in günah işlemesi nedeniyle gelecek kuşakların şeytana yenilmesi, bütün insan soyunun bu günahtan pay alması, onun itaatsizliği yüzünden çok kimsenin günahkâr olması, insanın bu yüzden reddedilmesi Hristiyan düşüncesinin günah doktrininin temel tartışma konularındandır. ${ }^{23}$

19 Dursun Ali Aykıt, "Pelagianizm'in Tarihi ve Öğretileri”, İstanbul Üniversitesi İlahiyat Fakültesi Dergisi 22 (2010), 188.

20 Espensberger, Die Elemente der Erbsünde nach Augustinus und der Frühscholastik, 82-86.

21 Espensberger, Die Elemente der Erbsünde nach Augustinus und der Frühscholastik, 85.

22 Gündüz, Pavlus: Hristiyanlı̆̆n Mimarl, 211.

23 Espensberger, Die Elemente der Erbsünde nach Augustinus und der Frühscholastik, 5. 


\subsection{Hristiyan Düşüncesinde Aslî Günahın Sebebi ve Neticesi}

Aslî günah kavramını bütüncül olarak açıklayabilmek için Hristiyan teologlar tarafından sorulan sorulardan birisi de günahın sebebinin ne olduğu sorusudur. Yasak meyveden yemek aslî günahın sebebi olarak görülmektedir. Nitekim Allah Âdem'i cennetine yerleştirdikten sonra O’na iyilik ve kötülüğ̈̈ bilme ăgacına yaklaşmamasını emretmiştir. ${ }^{24}$ Ancak Âdem de yaratıcı gibi ölümsüz olmak istediği için kendi iradesiyle yasak ağaca yaklaşmayı tercih etmiştir. ${ }^{25}$

Hz. Âdem'in cennetten çıkarılması meselesi insanın iradesinin çok yönlü bir şekilde farklı boyutlarıyla tartışılmasına da sebep olmuştur. İrade bir yandan günahın sebebi olarak görülürken diğger yandan insanoğlunun mükellef olmasının da asıl sebebi olarak görülmüştür. Çünkü eğer irade olmasaydı günah da olmazdı dolayısıyla eğer irade olmasaydı kişinin tekellüfü de anlamsızlaşırdı. Eğer bir kimse iradesini kullanamıyor ve akledemiyorsa bu durumda nasıl olur da Allah'a itaat etmesi hususunda sorumlu olmasından, ceza almasından yahut mükâfat elde etmesinden bahsedilebilir ${ }^{26}$ Bu yorumlama biçimiyle birlikte irade bir yandan kötülenirken diğer yandan bir gereklilik olarak karşımıza çıkmaktadır.

Mademki Âdem Peygamber hata/günah işledi ve onun nezdinde bütün âdemoğulları bu günahı miras olarak almaktadır bu durumda sorulması gereken soru şu şekilde tezahür etmektedir: Aslî günahı miras almanın sonucu nedir ve insanoğlu bu günahtan nasıl etkilenmektedir? Yaratıcı aslî günahtan dolayı insanoğlunu cezalandırmakta mıdır? Eğer öyleyse bu cezalandırma ne şekilde tebârüz etmektedir? Aslî günahtan âzâde olmak mümkün müdür? Aslî günahın kefareti olur mu şayet olursa aslî günahın kefareti nedir ve nasıl ödenebilir?

Yukarıdaki sorularla da bağlantılı olarak aslî günah kavramının bütün insanlığı etkileyen bazı sonuçları sözkonusudur ve bu günahın neticesinde insanoğlu bir takım yaptırımlarla karşı karşıyadır. Bu yaptırımların en önemlisi insanın dünyaya sürgün olarak gönderilmesidir. Nitekim havarilerin mektuplarında "bir insanla günahın dünyaya geldiği ve günah yüzünden

\footnotetext{
24 Nadide Şahin, "Hristiyanlıkta ve İslam'da Kurtuluş Anlayışı”, Sosyal Bilimler Dergisi/The Journal of Social Science 5/29 (2018), 482-483.

25 Ferruh Kahraman, Hristiyanlık ve İslamiyette Günah (İstanbul: Rağbet Yayınları, 2011), 42-43. 26 Aykıt, “Pelagianizm’in Tarihi ve Öğretileri”, 190.
} 
de ölümün geldiği yani ölüm cezasının verildiği” ifade edilmektedir. ${ }^{27} \mathrm{Bu}$ kadim günahın sonucunda insanın bu dünyaya sürüldügü ve bütün insanlığın Âdem Peygamber'in günahından pay aldığı yorumları Hristiyan teologların kendi aralarında uzun yıllar tartıştığı konular olagelmiştir.

Hristiyanlıkta aslî günahın neticesinde Âdem'in bütün insanların günahkâr olmasına sebebiyet verdiği düşüncesi fikri bir akide olarak yer almaktadır. Böylelikle ölümlü olmak bütün insanların kaderidir ve günahla kirlenen insanın artık bu günahı kaldırmaya mecâli bulunmamaktadır. ${ }^{28}$ Dünyada doğmuş olmak diğer bir deyişle ölümlü olmak; affın ve merhametin kaybedilmesi anlamına gelmektedir. Âdem iyiyi ve kötüyü bilme ağacına dokunmayacağına dair ahit vermişti ancak o meyveyi yedi ve affı (affedilmeyi) kaybetti. Artık bundan böyle insan "yol göstereni olmayan bir çocuk, dizgini olmayan bir at" gibidir. ${ }^{29}$ Dolayısıyla günah Âdem'in bedeninde yer tuttuğundan beri bütün insan soyu gerçekte onun ile başlayan ve nesilden nesile geçen bir etki altındadır ve artık bedende ölümün hâkim olmasının sebebi de günahtır. ${ }^{30}$

Aslî günah doktrinini savunan Hristiyan teologlara göre aslında her birimiz günahın hükümranlığına aidiz çünkü biz cennetten zamansal olana kovulduk "yani sonsuzluktan geçiciliğe, zenginlikten fakirliğe, güçten zayıflı̆̆ga” sürüldük. Eğer biz Âdem'den günahı miras almamış olsaydık Tanrı bu sefaleti bize vermezdi. Eğer biz bu suça ortak olmamış olsaydık bu hayata atılmazdık. Bütün insanlık bir şekilde bazen aynısıyla bazen farklı şekilde bu ezeli günahı tecrübe etmektedir ancak artık geç oldu çünkü günah insanla dünyaya geldi ve yeryüzünde onun etkisi yayıld.$^{31}$

İnsanoğlu bu günahın etkisi altına girdiği için onun bu günahtan kurtulması artık mümkün değildir. Pavlus'un günaha dair bu yaklaşımı yaşadığı çağın en kötümser yaklaşımı şeklinde karşımıza çıkmaktadır. Çağdaşlarının aksine o günahın hakimiyetinden insanoğlunun kurtulmasının mümkün olmayacağını savunmaktadır. İnsan tevbekâr olsa da onun günahın etkisinden kurtulması mümkün değildir. ${ }^{32}$

27Espensberger, Die Elemente der Erbsünde nach Augustinus und der Frühscholastik, 29. 28Aykıt, "Pelagianizm'in Tarihi ve Öğretileri”, 182.

29Espensberger, Die Elemente der Erbsünde nach Augustinus und der Frühscholastik, 87. 30Şinasi Gündüz, "Pavlus Teolojisinde Gnostik Unsurlar”, Dini Araştırmalar Dergisi 2/6 (2000), 67. 31Espensberger, Die Elemente der Erbsünde nach Augustinus und der Frühscholastik, 6. 32 Aydın, Pavlus Hristiyanlı̆̆ına Giriş, 246-247. 
Buna rağmen Hristiyan düşüncesinde bu günahın ağırlı̆̆ından insanı ve insanoğlunu neyin kurtarabileceği en temel sorulardan birisi olmuştur. Bu meyanda kefâret doktrini aslî günahın en önemli neticelerinden birisi -belki de en önemlisi- olarak karşımıza çıkmaktadır. Kefaret doktrini kısaca Hz. İsa’nın neden acı çekerek öldüğü veya çarmıha gerildiği sorusunun cevabını bulmayı da amaçlamaktadır. Bir bakıma İsa Mesih, insanların ruhlarını tutsak etmiş ve onları günah ve ölüme bağımlı kılmış olan günahın tesirini bertaraf etmek için fidye olarak verilmiştir. ${ }^{33}$

Kefâret doktrinine göre İsa Mesih Allah'ın emriyle yeryüzüne inerek insanlığı kurtarmak için gelmiştir. Çünkü insanlık kaçınılmaz kaderin baskısı altındaydı ve insanlığı baskı altında tutan bu kader Âdem Peygamber'in işlediği günahla şeytanın insan üzerinde hâkimiyet kurmasının sonucuydu ve bu kötülük insanın köleleşmesi anlamına gelmekteydi. ${ }^{34}$

İnsan kendi eliyle günah işlemiş, kendi eliyle ölümü haketmişti. Bu durumda insan yine kendi kıyama kalkmalı, kendi eliyle dirilmeliydi ve kefaret doktriniyle insanlık İsa Mesih'te dirilmektedir. ${ }^{35} \mathrm{Bu}$ açıdan Hristiyan akidesinin temellerinden olan vaftiz İsa Mesih'in ölümüne iştirak ederek kefaret ödemek anlamına gelmektedir. Hristiyan bir kimse vaftizle birlikte İsa Mesih'in ölümüne vaftiz edilmekte onunla birlikte gömülmekte ve onunla birlikte dirilmektedir. Dolayısıyla vaftiz günahtan temizleyen, aklayan ve insanı kutsal kılan bir banyo olarak görülmektedir. ${ }^{36}$

Âdem Peygamber'in cennetten çıkarılmasıyla ilintili olarak aslî günah kavramı Hristiyan düşüncesinde Allah-insan ilişkisinde belirleyici ve dinin aslî bir unsuru olarak ele alınmaktadır. Bu belirleyicilik bazen günah ile sevabın yahut diğer bir deyişle iyilikle kötülüğün rakip olarak ele alınması hatta günahın önünde herkesin diz çökmesi ve günahın hükümranlığı şeklinde de yorumlanabilmektedir. ${ }^{37}$ Bununla birlikte Hristiyan düşüncesinde "henüz daha aklını bile kullanamayan ve sorumluluk almamış bir çocuğun aslî günah ile itaatsiz olarak nitelendirilemeyeceği” düşüncesiyle aslî günah teorisini reddeden teologların varlığ da bilinmektedir. ${ }^{38}$

33 Şinasi Gündüz, Hristiyanlık (İstanbul: İsam Yayınları, 2013), 83-85.

34 Mehmet Aydın, Hristiyan Kaynaklara Göre Hristiyanlık (Ankara: Türkiye Diyanet Vakfı Yayınları, 2007), 64.

35 Kahraman, Hristiyanlik ve İslamiyette Günah, 40.

36 Katolik Kilisesi Din ve Ahlak İlkeleri, 305.

37 Espensberger, Die Elemente der Erbsünde nach Augustinus und der Frühscholastik, 5.

38 Espensberger, Die Elemente der Erbsünde nach Augustinus und der Frühscholastik, 92. 


\section{Mevlânâ'nın Düşüncesinde Hz. Âdem'in Yaratılışı ve Fıtratın Sâlimliği}

Hz. Âdem'in yaratılmasıyla ilgili olmak üzere Allah meleklere; “Ben yeryüzünde bir halife yaratacağım” dediğinde melekler doğrudan "Biz seni hamd ile tesbih ve takdis ederken yeryüzünde bozgunculuk yapacak ve kan dökecek birisini mi yaratacaksın?” diye karşılık vermişlerdi. Devamında vurgulandığı üzere meleklerin bu taaccüp içeren yaklaşımı bizzat yaratıcı tarafından "Ben sizin bilmediklerinizi bilirim"şeklinde meleklerin tedib edilmesiyle nihayet bulmuştur. ${ }^{39} \mathrm{Zemahşerî} \mathrm{ayetin} \mathrm{tefsirinde}$ انَجْعَلُ فيها ifadesinin bir taaccüb ifadesi olduğunu dolayısılyla meleklerin hikmet sahibi ve hayrı murad eden bir varlık olarak ehl-i tâât kullar yerine masiyete meyledecek kulları Allah'ın halife kılmasının sebebini anlayamadığını belirtmektedir. Âyetin devamında gelen "ben sizin bilmediklerinizi bilirim" buyurulması ve "Âdem'e bütün isimleri öğretti”"âyeti Hz. Âdem'in yaratılmasında hikmetler barındığını ve insanın yaratılmasının olumlandığını göstermektedir. ${ }^{41}$ Beydâvî, tefsirinde bu ayette melekler açısından iki müşkilin ortaya çıktığını vurgulamaktadır. İlk olarak tesbih eden meleklere rağmen kan dökme ihtimali olan insan zürriyetinin yaratılmasının Allah tarafından bizzat tercih edilmesi, ikinci olarak da onun ayrıca meleklere rağmen halife kılınmasıdır. Melekler şehvet ve öfkenin insanı kan dökmeye götürmesi ihtimaline karşı aklın da insanı marifete ve tefekküre götürme potansiyeline hâiz olduğunu tam olarak kavrayamadılar. İnsanın yaratılması iffet, şecaat, nefisle mücadele, adalet gibi erdemli vasıfların temeyyüz etmesi anlamına gelmektedir. Bu bağlamda insanın yaratılması onun akletme melekesini kullanarak şehvet, öfke gibi nefsânî vasıflarını terkedebilmesi ve iffet, şecaat gibi vasıfları irade etmesi anlamına gelmektedir. Allah'ın,'ben sizin bilmediklerinizi bilirim' hitabı da hata, nâkıslık ve kusur işleme ihtimaline rağmen tecellî-i hikmet açısından yaratmayla birlikte iradenin olumlandığını göstermektedir. ${ }^{42}$

39 Kur'an Yolu (Türkçe Meâl ve Tefsir), çev. Hayrettin Karaman vd. (Ankara: Diyanet İşleri Başkanlığı Yayınları, 2014), el- Bakara 2/30.

40 el- Bakara $2 / 31$.

41 Zemahşerî, Ebu'l-Kâsım Cârullah Mahmûd b. Ömer b. Muhammed el-Harizmî, El-Keş̧̧âf 'an-Hakā'ikn Gavâmizì 't-Tenzîl ve 'uyûni'l-Ekāovîl fî-Vücûhi't-Te'vîl (İstanbul: Türkiye Yazma Kurumlar Başkanlığı Yayınları, 2016), 1/344.

42 Beydâvî Nasıruddîn Ebû Said Abdullah bin Ömer bin Muhammed eş- Şirâzî, Envâru't-Tenzîl ve Esrâru't-Te'vîI (Beyrut: Dâru'-r Reşîd, 1421), 83. 
Mevlânâ insanın iyi ile kötü arasında tercih etme iradesine sahip olmasinı kara ve deniz metaforlarıyla ifade etmektedir. Onun ifadesiyle melekler letâfet âleminden oldukları için, onların kesif olan kara tarafına yolları yoktur. Hayvanlar ise cinsi âlem-i kesâfetten mahlûk oldukları için onların da bahr-i letâfetten haberleri yoktur: ${ }^{43}$

"Sen 'Kerremnầ üzere benı̂Âdem'den bir padişahsin ki / hem karaya hem denize adim atabilirsin.

'Ve hamelnâhüm fil berri vel bahri / onları kara üzerine yüklettik' hükmünce ilerle.

Melekler için karaya yol yoktur / Hayvanlarm da denizden haberleri yok.

Sen, ten itibarıyla hayvan, can cihetinden meleksin / Bu suretle hem yerde hem de gökte yürürsün." ${ }^{4}$

İnsanın hem iyiliğe hem kötülüğe meyilli yaratılması ve iradesi arz ve semâ kavramları üzerinden de açılanmaktadır: "Kendini yahut Âdem’i görmez misin nasıl semâlar ile arz arasına girmiştir.” ifadesiyle vurgulanmak istenen insanın hem zâhirî-bâtınî hem de iyi-kötü vasıfları kendinde toplayan bir varlık olduğudur. İlk anlam itibariyle insan cismen yerküre ile feza katları arasında bulunmaktadır. Bâtınî anlam itibariyle ise her bir insanın kendisinin "arz"1 olan bedenle yine kendisinin "semâ"sı olan ruh arasında şahsiyyet bulmasıdır. Bu açıdan insan esmâ-i Hakk'ın tecelligâhı olarak halife kılınmış hem ayıran hem de toplayan kavşakta konumlanmıştır. ${ }^{45}$

Melekler salt akıl, hayır ve iyilik vasıflarıyla mevsuf oldukları için onların bir işi yerine getirme ya da irade etme seçenekleri yoktur. Âdemoğulları ise bunun aksine tercih etme ve irade ile donanmıştır. İnsanın bu seçkinliği insanın ilâhî isimlerin tecelligâhı olmasıyla irtibatlandırılmış ve Âdem/ insan ilâhî isimlerle donatılmış olmakla meleklerden farklıdır. ${ }^{46}$ Çünkü Allah'ın Âdem'i yaratmayı irade etmesi onun benlikle birlikte gaflet ve

\footnotetext{
43 A. Avni Konuk, Mesnevî-i Şerif Şerhi (İstanbul: Kitabevi Yayınları, 2012), 4/506.

44 Mevlânâ, Mesnevî-i Manevî, 2/ 3759-3762. Makâle de Mesnevî'de yer alan beyit numaraları Adnan Karaismailoğlu ve Derya Örs’ün Farsça “Mesnevî-i Ma'nevî” isimli neşrinden alıntılanmakla birlikte Türkçe beyitler Abdülbaki Gölpınarlı ve Veled Çelebi İzbudak tercümelerinden de istifâde edilerek bazen aynısıyla bazen küçük değişikliklerle aktarılmıştır.

45 İbn Arabî, Âdem Kelimesindeki İlahi Hikmet Fassı, çev. Mehmed Ali Nusreddin (İstanbul: Litera Yayınları, 2016), 8-9.

46Ahmet Avni Konuk, Fusûsu’l-Hikem Tercüme ve Şerhi (İstanbul: Marmara Üniversitesi İlâhiyat Fakültesi Yayınları, 1999), 1/139-141.
} 
teyakkuz ya da ceza ile mükafat vadisinde konaklaması gereğidir. ${ }^{47}$ Nitekim Mevlânâ insanın bu durumunu Allah ona isimleri öğretti ${ }^{48}$ âyetine mazhar olan Âdem bile şeytanın hilesine kapılınca bu kapılış kendisinin cennetten çıkarılmasına sebeb oldu diyerek açıklamaktadır. ${ }^{49}$

İnsanın halifeliği tasavvuf düşünce geleneğinde aynı zamanda âlemin yaratılışındaki insicâmı ve güzelliğin yorumlanma biçimini hatırlamayı da gerektirmektedir. Âlem en mükemmel şekilde yaratılmış olup âlemde zerreden kürreye her şey Hakk'ı tesbih etmektedir. Ancak âlemde herşey yaratıcıyı sürekli tesbih etse de yaratılıştaki tekâmül ancak Hz. Âdem’in yaratılmasıyla nihayet bulmuştu. Bu açıdan Âdem/insan beşeriyet ve âdemiyet cihetinden süflî ve ulvî hakikatlarin cümlesini kendinde toplamakla kâinâtta seçkin ve mükellef kılınmıştır. Âlemde mevcut olan her bir hakikat insanda da mevcuttur. İnsan âlemin hülâsâsı ve özüdür. İnsân-1 kâmil de âlem-i hilkatin dünyaca ve ahiretçe sebebi olmak cihetinden gözün gözbebebeği mesabesindedir. ${ }^{50} \mathrm{Bu}$ açıdan Mevlânâ’nın düşünce ekseninde insanın yaratılması seçkinlik olarak değerlendirilmektedir ve kâinatın taçlandırılması anlamına gelmektedir. Mevlânâ bu durumu şöyle açıklamaktadır:

"İnsan cevherdir, gök ise onun arazıdır / Her şey fer'idir, her şey basamak, gaye odur.

Ey akıllar, tedbirler, fikirler kulu kölesi olan bey, mâdemki böylesin, kendini neden böyle ucuza satıyorsun?

Sana hizmet etmek, bütün varlık âlemine farzdir / Bir cevher, neden arazdan ihsan ister ki?",51

Âdemoğlu haricinde ne nebâtın ne de cemâdın irade ve ihtiyarları mevcut değildir. Hayvânâtın irâde ve ihtiyarı ise tabiî olup iki durumdan biri hususunda ihtiyarda bulunmak ve ihtiyar ettiğiyle âmil olmak bizatihi insana mahsustur. Bu durumda ister nebât cinsinden ister cemâd yahut hayvânât cinsinden bütün mahlûkâtın murâd-ı ilâhî ile hareket etmeleri sebebiyle ubûdiyyet üzere yaşamalarına rağmen kulluklarında zevk ve şevk hâsıl olmadığg söylenebilir. ${ }^{52}$ Mevlânâ iradeyi mevzu bahis ederken

47 İbn Arabî, Âdem Kelimesindeki İlahi Hikmet Fassı, 97.

48 el- Bakara 2/31.

49 Mevlânâ, Mesnevî-i Manevî, 2/2693-2696.

50 Konuk, Fusûsu'l-Hikem Tercüme ve Şerhi, 1/56-59.

51 Mevlânâ, Mesnevî-i Manevî, 5/ 3575-3577.

52 Konuk, Mesnevî- $i$ Şerif Şerhi, 2012, 6/235-236. 
bir yandan iradeyi iyiliğ̈i ve kötülüğü tercih sebebi olarak görmekte diğer yandan iradenin yaratıcıyı bilmenin gerçek sebebi olduğunu vurgulamaktadır. Bu yüzden Mesnevî'de irade insanı kötülüğe sevketme potansiyeliyle birlikte mârifetullah ve Hakk'ı idrak etmenin sebebi olması cihetinden öne çıkmakta ve methedilmektedir. ${ }^{53}$ Mevlânâ şöyle demektedir:

"İhtiyar (dileğini yapmak kudreti), taatin tadı tuzu oldu / yoksa bu felek de ihtiyarsiz iradesiz dönüp durmakta.

Fakat onun dönüşü için ne sevap ne de ikâb vardır / çünkü sevap da ikâb da ihtiyarî olarak yapılan işe verilir.

Zaten bütün âlem Hakk'ı tesbih etmektedir / ancak (onlarm) tesbihine bir sevap olmaz.

Erin eline kılıç ver de, onu âcizlikten kurtar / tâ ki ya gazi olsun, ya yol kesici eşkiya olsun.

Âdem, 'Kerremnâ' sirrına, dilediğini yapabilme kudretiyle erişti... / (insanların) yarısı bal arısı oldu, yarısı yılan!'”54

İyiyi ve kötüyü tercih edebilme yetisi olarak Hristiyan düşüncesinde iradenin bazen methedilmekte bazen zemmedilmekte olduğu belirtilmişti. Ancak Hristiyan düşüncesinde iyiyi ve kötüyü seçme potansiyeli bağlamında ilk günah her zaman âdemoğullarının fiilerinde belirleyici konumdadır. Bu açıdan bir kimse cehaleti nedeniyle doğruyu yapamadığında ya da yanlış yaptığında bu günahların kökeni özgür iradeyle işlenen ilk günahtır sonraki günahlar sadece bu ilk günahın sonucudur. $\mathrm{Bu}$ durumda bilinmeli ki yanlışları gerçekler olarak kabul etmek, istemeden hata yapmak, bütün bunlar insan doğasının bir gereği değil mahkûm edilmiş bir suçlunun cezalarıdır. ${ }^{55}$

Bununla birlikte bazı Hristiyan teologlar iradeden dolayı Tanrı'yı suçlamanın gerçekçi olmadığını aksine özgür iradeyle ve yeterli bir güçle donanmış herkesin bundan dolayı Tanrı'ya borçlu olduğu düşüncesini de dile getirmeyi ihmal etmemişlerdir.

53 Zafer Erginli, “Mevlânâ İrfanında İnsan Prototipi Olarak Hz. Âdem”, Marife: Dini Araştırmalar Dergisi 7/3 (2007), 75.

54 Mevlânâ, Mesnevî-i Manevî, 3/3286-3290.

55Augustinus, İstencin Özgür Tercihi Üzerine, çev. Metin Topuz (İstanbul: Say Yay., 2015), 155. 
Mevlânâ’nın düşüncesinde ise iyi ile kötüyü irade edebilmek Hakk'ın âdemoğlunu bir yandan sorumlu bir yandan da doğuştan seçkin ve müşerref kılmasıyla ilgili bir durumdur:

"İnsan, "Kerremnâ" kır atının üzerinde süvârdır, onun elinde ihtiyar dizgini vardır."56

\subsection{Mevlânâ'ya Göre Dünya Hayatı: Hayatın ve Ölümün İnsicâmı}

Hristiyan düşüncesinde iyilikten yüz çevirme potansiyeli bağlamında irade ve günah kavramları, Adem'in cennetten sürülmesi, insan soyunun aslî günahtan etkilenmesi ve kötülügün dünyaya yayılması bağlamında yorumlanmaktaydı. Bu açıdan dünya hayatı zemmedilmekteyken aslî günahın bir neticesi ve insanın cezalandırılması olarak telakki edilmektedir. Mevlânâ da dünyayı bazen canların hapishanesi, ${ }^{57}$ bazen fani bir hasta, ${ }^{58}$ bazen de matem konağ ${ }^{59}$ olarak tasvir etmektedir. Dünya hayatıyla ilgili dünyanın zemmedilmesi cihetinden bu türden bir yaklaşım biçimine sadece Hristiyan düşüncesinde değil, Mesnevî̀de de -ve bazen ilk dönem klasik tasavvufî eserlerin zühd bahsinde- rastlamak mümkündür. Ancak bu yaklaşım biçimi Mevlânầnın dünya hayatını ruhların aslî vatanı olarak görmemesinden kaynaklanmaktadır. Nitekim Mevlânâ’ya göre vatan kavramı "vatan-1 rûh" ve "vatan-1 cesed/vatan-1 kevnî" şeklinde ikiye ayrılır. Hz. Âdem' in cennetten çıkarılarak gönderildiği dünya hayat1, vatan-1 cesed/vatan-1 kevnîdir. Vatan-1 kevnîde/vatan-1 cesedde olan kimsenin en büyük amacı vatan-1 rûha dönmektir. Cüneyd-i Bağdâdî̀nin (ö. 909) de vurguladığı üzere bedenlerin dünyevîliği sözkonusu olsa da ruhlar nûrânîdir ve onların vatanları âlem-i gaybtandır. Rûh beden ve beşeriyet kaydında kaldığı müddetçe hasret ve ızdıraptan uzak değildir. Bu düşünce Mevlânâ’nın düşüncesinde, sazlıktan koparılan ney sembolü üzerinden "asıl-fer" ilişkisi cihetinden ele alınmaktadır. ${ }^{60}$

56 Mevlânâ, Mesnevî̀-i Manevî, 3/ 3299.

57 Mevlânâ, Mesnevî̀-i Manevî, $1 / 526$.

58 Mevlânâ, Mesnevî̀-i Manevî, 1/1296.

59 Mevlânâ, Mesnevî̀-i Manevî, 5/1768.

60 Muammer Cengiz, "Tasavvuf Tarihinde Elest Mîsâkına Dair Yorumlar”, Uluslararası Sosyal Araştırmalar Dergisi 10/50 (Haziran 2017), 915; Ali Çoban, Cezire-i Mesnevî ve Şerhlerine Göre Mevlevî Sülûku (Konya: Palet Yayınları, 2021), 185-186. 
Bu durumda dünya hayatı Mevlânâ'nın dünyaya dair bu tasvirleri dünya hayatının kötü olduğu tezinden ve dünyada kötülüğün hâkim olduğu düşüncesinden değil, dünyanın Mâşûk-1 Hakîkî’yi perdelemesi açısından ve Mevlânâ'nın vatan-ı aslîye kavuşma iştiyakından ileri gelmektedir. Nitekim Mevlânâ bunu şöyle anlatmaktadır:

"Bu geçidin ayrılı̆̆ı sana şedid gelir, oysa o geçidin ayrılı̆̆ını daha şedid bil.

Şayet sana nakıştan ayrılmak bu kadar güç gelirse acaba nakkaştan ayrlmak ne kadar şedid olur?

Ey kişi aşağılık dünya ayrılı̆̆ına sabretmiyorsun dost olan Hüdâ’nın ayrılı̆̆ına nasıl sabredeceksin?’"61

Diğer yandan sazlıktan koparılan "ney" metaforundan da anlaşılacağı üzere dünya hayatı bir yandan “vatan-ı kevnı̂” ve "fer” olarak tasvir edilmekle birlikte, diğer yandan Mâşûk-1 Hakîkî̀ye giden yolda önemli bir konaklama yeridir. Bu cihetten vuslat-1 Hakk için bu dünya bir ekim tarlası bir kazanç yeridir.

Mevlânâ bu durumu şöyle açıklamaktadır:

"Kim ki âkıbeti daha iyi görür o çok mes’uddur, mahsulü gören daha ciddiyetle eker.

Çünkü bilir ki bu ekim dünyası, mahşere hazırlanmak, (ekin) devşirmek içindir." "62

\subsection{Hz. Âdem'in Cennetten Çıkarılması ve Âdemoğlunun Bir Eylemi Olarak Günah ve Tevbe}

Farsça kökenli olan ve suç anlamına gelen günah kelimesi, ${ }^{63}$ Kur'ân-1 Kerîm'de ve hadislerde genel olarak ism, zenb, vizr, cünâh ve hûb kelimeleriyle karşılık bulmaktadır. ${ }^{64}$ Dînî bir kavram olarak ilâhî emir ve yasaklara aykırı fiil ve davranış anlamında kullanılmaktadır. ${ }^{65}$

Mevlânâ'nın günah ve tevbe tasavvurunu anlayabilmek için Âdem Peygamber'in cennetten çıkarılması konusunda serdettiği beyitleri irdelemek gerekir. Bu bağlamda şu sorular onun beyitlerinde cevaplamayı

61 Mevlânâ, Mesnevî-i Manevî, 4/3209-3211.

62 Mevlânâ, Mesnevî̀-i Manevî, 4/ 2997.

63 Sâmi Şemseddin, Kâmûs-ı Türkî (İstanbul: Dersaâdet Yay., 1317), “Günah”, 1185.

64 Zebîdî, Tâcü’l-'arûs (Kuveyt: Matbât-ü Hukûmet-il Kuveyt, 1407), “Zenb”, 2/436.

65 Ferruh Kahraman, "Bir Tefsîr - Kelâm Problemi: Hz. Âdem’in Yasak Ağaca Yaklaşması”, Sakarya Üniversitesi İlahiyat Fakültesi Dergisi 15/27 (2013), 192. 
gâye edindiği sorulardır. İlk olarak gerçekte Âdem (a.s.) "Âdem'e isimleri öğretti” bilgeliğiyle donatılmışken Hakk'ın halifesi olmak vasfına nâil olmuşken nasıl da bu hataya meyletti? Bunca âlim vasfiyla anılmasına ve hikmet sahibi olmasina rağmen onun cennetten kesâfet âlemine düşüşünün sebebi tam olarak nasıl açıklanabilir? Âdem Peygamber hata ile hemhâl olduğunda ve onun zürriyetinden olmak cihetinden âdemoğlu günaha düştügünde onun Allah ile olan rubûbiyet-ubûdiyyet ilişkisi hangi minval üzere ilerlemektedir? Günah-tevbe bağlamında tevbeyle birlikte âdemoğlunun fiil ve amelleri Hakk'nn gazab ve cezasından muâf olabilir mi?

Mevlânâ bu sorular sadedinde ilk olarak Âdem Peygamber'in hataya düşmesini onun "ağaca yaklaşmayın"66̂yetini yanlış tefsir etmesine bağlamaktadır. Hz. Âdem ağaca yaklaşmayın âyetinin nehy-i tahrîmî mi yoksa nehy-i tenzîhî mi olduğu konusunda tereddüde düştü ve sevk-i tabiî ile ağaca meyletti. ${ }^{67}$

Hz. Âdem'in ağaca yaklaşması şeytanın ona vesveseyle hücüm etmesi neticesinde onun bir müddet de olsa teyakkuz hâlini kaybetmesine ve dalgınlığa düşmesine sebeb olmuştur. Bu dalgınlığa düşme hâdisesi bahçıvanın ayağına diken batması diye tabir olunur ki geçici ve ârızî bir durumdur: 68

"Bahçıvanın ayağına diken batınca hırsıf firsat buldu, (onun) esvabın çalıp kaçtı." 69

Teyakkuz hâli sona erince Âdem Peygamber hatasını farketti ve Rabbena zalemnâ diyerek tevbe etti. ${ }^{70}$ Mevlânâyya göre bu âyet-i kerimedeki 'zulüm' kelimesi zulmet olarak anlaşılmalıdır. Dolayısıyla biraz daha açıklamak gerekirse Mevlânâ'nın bu beyitle vurguladığı üzere âyette; 'Ey Allah'ım biz nurânî bir âlemde korunmakta iken, üzerimize karanlığı davet ettik de ilâhî kaza üzerimize zulmet ve karanlık getirdi ve nefsimizi bu ağaca yaklaştırmakla kendimize zulmettik. Şayet sen bizim nefsimize nûr indirmez ve nefsimizi nûrunla kaplamaz da bize merhamet etmezsen biz hüsrân ve uzaklık içinde kalırız. Dolayısıyla bu beyitlerden anlaşılacağı üzere, “Rabbenâ zalemnâ" demek, “ân”lı bir örtünme hâli

66 el- Bakara 2/35.

67 Konuk, Mesnevî-i Şerif Şerhi, 2012, 1/386.

68 Konuk, Mesnevî-i Şerif Şerhi, 2012, 1/387.

69 Mevlânâ, Mesnevî̀-i Manevî, 1/1253.

70 Mevlânâ, Mesnevî̀-i Manevî, 1/1255. 
geldi de basiretimiz örtüldü ve kalp gözümüzün önünde meleklerin yolu kayboldu demektir.?11

Mevlânâ'nın Hz. Âdem'in pişmanlık duymasından sonra dünyaya gönderilmesini bütüncül bir perspektiften analiz edebilmek için onun insanın söz ve amellerinin akamete uğramasını "kırılmış inci" metaforuyla nasıl yorumladığ 1 cihetinden de irdelemek gerekmektedir. Mesnevî'de bu metaforik anlatımdan hemen sonraki beyitlerde "Rabbenâ zalemnâ" âyetini zikreden Mevlânầya göre pişmanlığa sebeb olacak bir kesintiye uğrayan her işin sonu başladığı haliyle mütemâdiyen sürüp gitmeyebilir. Nitekim ehl-i mâtemin sözleri de kırık inci misâli (dürr-i şikeste) bazen gayret-i ilahiyye değirmeni altında kırık hâle gelir ve öğütülür ancak diğer yandan "dürr-i şikeste"nin ziya ve parlaklığı daha da kavîleşir:"72

"Ey inci kırıldiğın için gam etme; çünkü kirlmaktan parlaklik olacaktır.

Böyle kırılmış bağlanmış söylemektir ki Hakk onu sonunda doğru kılar çünkü O ganîdir."ᄁ3

Diğer açıdan kırılmış olmak buğdayın değirmende ufalanması olarak teşbih edilir ki buğday değirmende ufalanmadıkça nân-ı hayr yani hayırlı ekmek/hayırlı lokma olmaz. Şayet buğday kırılıp ufalanmasa, öğütülüp fırında pişmeseydi beşerin vücûduna iyilik ve hayır getirecek tekâmül safhasına erişemezdi. ${ }^{74}$ Eğer bir kimse, bir eylem yahut bir şey munkatı olduysa -ki buğday da ait olduğu topraktan munkatı oldu ve ayrı düştü Hz. Âdem cennetten dünyaya gönderildi- bu hal onun ziyan ettiği ve noksan kaldığı anlamına gelmeyebilir. Aksine o belki de buğday gibi hayırlı lokma ve latif bir gida olacaktır. ${ }^{75}$

"Buğday, kirıldı, ufalandı, un haline geldi de dükkâna girdi, güzel ekmek oldu." "76

Kişinin tevbeyle birlikte acziyetini idrak ile birlikte hatasını telâfi ederek sorumluluk alması beşer olmaktan yeniden insaniyete vâsıl olması anlamına gelmektedir. ${ }^{77} \mathrm{Bu}$ açıdan günah insanın zulmette kalması, ârızî bir karanlık hali, ilâhî rahmet damlalarından ve nûrdan örtülü kalması

\footnotetext{
71 Konuk, Mesnevî-i Şerif Şerhi, 2012, 1/387.

72 Ahmet Avni Konuk, Mesnevî-i Şerif Şerhi (İstanbul: Kitabevi Yayınları, 2008), 7/110.

73 Mevlânâ, Mesnevî-i Manevî, 4/ 342-343.

74 Konuk, Mesnevî-i Şerif Şerhi, 2008, 7/110.

75 İsmâil Rusûhî Ankaravî, Şerh-i Mesnevî (İstanbul: Matba'a-'i 'Amire, 1872), 4/73.

76 Mevlânâ, Mesnevî-i Manevî, 4/344.

77 Erginli, “Mevlânâ İrfanında İnsan Prototipi Olarak Hz. Âdem”, 77.
} 
halidir. Bununla birlikte Âdem Peygamber'in eylemi bir yandan cüz'̂̂ iradenin ortaya çıkması ve onun kendi tercihi iken diğer yandan kazay-1 ilâhî olarak tavsif edilmektedir. Nitekim bu merhalelerden geçerek Âdem Peygamber de acziyetini idrak ederek rabbenâ zalemnâ diyerek nefsini tahkirle kınadı. ${ }^{78}$ Mevlânâ bu durumu şöyle ifade etmektedir:

"Ey âşık, madem senin de suçun âşikâr oldu o halde artık suyu yağı bırak da kırık dökük ol!

Onlar Âdem'in has çocuklarıdır ki, "Rabbimiz, biz nefsimize zulmettik" nefhasini okurlar.' 79

İsyankâr olan bir kimse nehyedilen fiillerden tevbe ederek kendini kınamayla mevsuf olunca, o kimsenin dinin emirlerine olan muhalefeti zâil olur ve dolayısıyla onun fiillerinin çirkinliği de ortadan kalkar ve geriye yalnızca kendi zâtının güzelliği kalır. Böylelikle Allah Teâlâ onun fenalık ve çirkinliklerini güzellik ve iyiliğe tebdil eder.

Beşer olmak/kalmak külliyyen mânâdan mahrum olmak değilse de manâya kâmilen ehil olamamak anlamına gelmektedir. Beşerlik ilâhî isimleri barındırmakla birlikte arzdan olan benlik kaydına bulanmışlıktır. Âdem/insan tevbeyle benlik kaydından ve kendine/kendi nefsine iyi davranmaktan kurtulmakta kendini beşeriyetin dar menfaat semasında sıkışmaktan âzât etmektedir. Bu âzâdelik âdemoğlunun kendini iblislik taslayan beşer vasıflarından da kurtarması demektir. ${ }^{80} \mathrm{Bu}$ açıdan tevbeyle birlikte günahı da terk etmeyle kişinin kötü amellerinin silinmesi umut edilir ki bu nasuh tevbedir. Bal nasıl bal mumundan arınıp saf hale gelirse tevbe de içinden riyâ ve çirkinliklerin temizlenmesiyle kişiyi arınmış hale getirir. ${ }^{81} \mathrm{Bu}$ yüzden bir kimsenin tevbesi kendini bu kayıtlanmalardan kurtaramayan şeytanın yeniden bîçâre kalmasının tebârüz etmesi, rahmetin öne geçmesi iyiliğin hâkim olmasıdır:

"Hakk ümitsizliğin sultasın yıkmıştır, böylece günah tâate dönmüştür.

O seyyiâtı tebdil ettiğinde gammazlara rağmen bunu tâat yapar.

Bundan dolayı kovulmuş şeytan hasedinden çatlar, iki parça olur." ${ }^{2}$

78 Konuk, Mesnevî̀-i Şerif Şerhi, 2012, I/387-388.

79 Mevlânâ, Mesnevî-i Manevî, 345-346.

80 İbn Arabî, Âdem Kelimesindeki İlahi Hikmet Fassı, 50-51.

81 İsmâil Rusûhî Ankaravî, Minhâcu'l Fukarâ (İstanbul: İnsan Yayınları, 2011), 237.

82 Mevlânâ, Mesnevî̀-i Manevî, 1/3836-3838. 
Mevlânâ'nın günah tasavvuru özne ve insanı bütünüyle esir alan bir eylem değil; edilgen ve insana hükmedemeyen ârızî bir eylemdir çünkü insanın özünde Hakk'ın indinde hoş ve güzel olanı tercih etmek yahut kötülüğe meyletse de ondan dönüp tevbe etmek aslî olandır. Bu bağlamda günah ve kötülük ârızî, tevbe ise aslîdir. ${ }^{83}$ Buna rağmen günahta süreklilik kişinin kendi varoluş gayesini ötelemesi anlamına gelmektedir. Günahta 1srar eden kimse bir zaman sonra dinin hükümlerini kendi zan ve kanaatince tevil etmeye kalkışır. Günahlar bir zaman sonra alışkanlığa dönüşerek âsî kimsenin gözünde ve gönlünde normalleşince o kimse dinin hükümlerini nefsânî fikirlerle tevil etmeye kalkışabilir. Gitgide tevbeden uzaklaşması neticesinde bu hal iman cevherini paslandırarak kişinin Hakk'ın gazabına uğramasına, emir ve nehiylerle kendi arasında aşılması müşkil engellerin oluşmasına sebeb olabilir. ${ }^{84}$

Mevlânâ bu durumu ifade etmek için beyaz bir kâğıda yazılan yazı ile karalanmış bir kâğıda yazılan yazı arasındaki farktan bahsetmektedir. Nitekim beyaz kâ̆̆ıda yazılan yazı hemen okunmaktayken karalanmış bir kâğıda yazılanı okumak müşkil bir durum arzeder. Mevlânâ bu hususu şöyle ifade ediyor:

"Ak kâğglda bir yazı yazsan o yazı görülür görülmez okunur / ama yazılı bir kâ̆̆gda yazı yazsan okunması güçleşir, anlaşılmaz, yanlış okunabilir.

O karalık karalığının üstüne gelmiştir; iki yazı da körleşmiştir, mânâsı da kalmamıştı. ${ }^{85}$

(Bir kimse de) ayak direr de kötülïğ̈̈ sanat edinir, düşüncesinin gözüne toprak saçarsa;

Tevbe etmeyi aklina bile getirmezse, artık o suç tatl görünür gönlüne, derken- derken de dinsiz olur gider.

o pişmanlik, o yâ Rabbi deyiş gider de ondan; gönül aynasina beş kat pas çöker.

Paslar demirini de yemeye koyulur, temelini de yok etmeye girişir. ${ }^{86}$

\footnotetext{
83 Erginli, “Mevlânâ İrfanında İnsan Prototipi Olarak Hz. Âdem”, 77.

84 Konuk, Mesnevî-i Şerif Şerhi, 2012, 4/412.

85 Mevlânâ, Mesnevî̀-i Manevî, 2/3368-3369.

86 Mevlânâ, Mesnevî-i Manevî, 2/3364-3366.
} 
Öyleyse çareler bulana sığınmaktan başka ne çare var, bakırın ümitsizliğine iksir onun bakışıdır ancak"s7

Mevlânâ’nın insan ve insanın eylemi bağlamında günah tasavvurunu anlamak için onun insanı ve insanın seyyiât yahut hasenât cinsinden bütün eylemlerini zât-sıfat, cevher-araz bağlamında yorumladığını da izah etmek gerekmektedir. Bu açıdan insan cevher iken cism-i insana taalluk etmekliği açısından insanın cümle harekâtı ârâz olup cisimden her an zâil olmakla cismin üzerinde müdâm değildir. Harekât-ı insâniyye ve cismaniyye harekâtın "ayn"ı değil zıllidir. Bu açıdan sadece amel-i seyyie değil amel-i hasene de ârâzlardan mahsûbtur. Her ne kadar ârâzdan cevher, cevherden ârâz husûle gelirse de cevher-i rûh-i hayvânî ârâz olan âmâl-i sâlihâ ile cevher-i rûh-i insânîye tebeddül olmayabilir. ${ }^{88}$ Mevlânâ bu durumu şöyle izah etmektedir:

"Bu namaz ve oruç arazlarmı Hakk'a nasıl ileteceksin ki? / Çünkü araz, iki zaman zarfinda baki kalmaz, yok olup gider, bir anliktır.

Arazları götürmeye imkân yoktur /Fakat (arazlar) cevherden hastalikları giderirler.

Bostan ekmek arazdir, Bostanda biten mahsul cevherdir. Zaten maksat da budur.

Kimya ile uğraşmayı da araz bil / eğer o kimyadan bir cevher elde ettiysen onu getir.

Aynayı cilâlamak da arazdır / Fakat bu arazdan tertemiz bir ayna cevheri meydana gelir.

Şu halde 'Ben ibadette bulundum' deme / o arazlardan elde edileni göster, ürkme." ${ }^{89}$

\section{Sonuç}

Makalede Hristiyan düşüncesinde bir öğreti olarak teşekkül eden aslî günah kavramından yola çıkılarak Mevlânâ’nın düşüncesinde günah ve tevbe kavramının anlamı izah edilmeye çalışıldı. Aslî günah teorisi bazı Hristiyan teologlar tarafından da eleştirilmekle birlikte Hristiyan 
düşüncesinde dinin aslî bir unsuru olarak yerini korumuş ve Hristiyanlığ ciddi bir biçimde şekillendirmiştir. Bu açıdan Âdem Peygamber'in eylemi olarak aslî günah Hristiyan düşüncesinde bütün insanlığa miras olarak kalan bir günah konumundadır. İnsanlığa devreden bu miras, aynı zamanda kötülügün dünyaya yayılması ve âdemoğullarının aslî günahtan dolayı bu dünyaya sürgün olarak gönderildiği düşüncesiyle ilintilendirilir. Artık âdemoğulları bu günahın ve dolayısıyla kötülüğün esareti altındadır, dünya hayatı da bu günahın neticesinde sürgün yeridir.

Mevlânâ'nın eserlerinde de insan-dünya ilişkisi bağlamında dünya hayatı zaman zaman zindan, kuyu, gurbet gibi metaforlarla izah edilmekte bazen de insanın dünyaya düşüşünden bahsedilmektedir. Mevlânâ’nın dünya hayatıyla ilgili bu tasvirleri Hristiyan düşüncesinde de mevcut olan dünya hayatının sürgün yeri olduğu tezini anımsatabilir. Nihayetinde Hz. Âdem'in dünyaya gönderilmesi konusu semâvî dinlerin ortak konusu olması hasebiyle benzer yorumların olması kaçınılmazdır. Ancak bütüncül açıdan bakıldığında Mevlânâ’nın bu tasvirleri dünya hayatının vatan-ı aslî olarak görülmemesinden kaynaklanmaktadır. Sadece ney ve şeb-i ârûs kavramları onun dünyayı Hristiyan düşüncesinde varolan biçimiyle Allah'ın insanı cezalandırması şeklinde yorumlamadığını aksine dünyayı Yaratıcı'dan ayrı düşmek bazen de dünyanın yansımalarıyla perdelenerek Elest Bezmi'ni unutmak bağlamında ele aldığını göstermektedir. Bu açıdan dünya hayatı kötümserlik barındıran bir mekân değil ancak bir mekân-1 kevnî, bir gurbet hayatıdır. Mâş̧uk-1 Hakîkîye vuslatın köprüsü, anlam ve değer barındıran bir ekim tarlasıdır.

Aslî günah kavramı Hristiyan düşüncesinde bazen iradenin kötülügüu, bazen iyiliği ve kötülüğü bilme iştiyakı ile açıklanmaktadır. Bu bağlamda Hristiyan düşüncesinde iradenin kötülüğe meyletmesi günahın sâiki olarak görülürken irade yerilmektedir. Bazen de iradenin yaratılışta iyi olduğu ve günahla birlikte tahrip olduğu düşüncesi mevcuttur. Hristiyan teologlardan bazılarının kişinin bireysel iradesini olumladıklarını insanın kötü eylemlerini aslî günaha ircâ ettiklerini ifade edebiliriz. Bazı metinlerde de aslî günah insanın Tanrı'nın rahmetine güvenmemesi ve Tanrı'nın dostluğuna yakışmayacak şekilde davranması olarak yorumlanmaktadır. Mevlânâ’nın düşüncesinde ise irade insanın yaratılışıyla birlikte iyi ile kötüyü temyiz etttikten sonra eylemin ircâ mahalli olarak görülmekte ve insanı meleklerden ve diğer mahlûkâttan ayıran, sorumlulukla 
birlikte onu seçkin kılan bir unsurdur. Bununla birlikte âdemoğullarına aslî günah değilse de Hz. Âdem'in fitratının miras kaldığı söylenebilir. İnsanoğlu Hz. Âdem'den fitratla birlikte seçme kabiliyetini miras almıştır ve dolayısıyla seçmek ya da irade etmek hataya düşme potansiyelini de barındırmaktadır.

Hz. Âdem'in hatası -zelle- ve cennetten çıkarılması, insanın yaratılması, halifeliği gibi konular bütün semâvî dinlerin ortak konusudur. Mevlânâ dünya hayatına dâir tasavvurlarıyla, Hz. Âdem'in hatası ve cennetten çıkarılmasını yorumlama biçimiyle sadece İslâm tasavvuf düşüncesinin insan ve insanın eylemi olarak günah kavramını izah etmekle yetinmiyor semâvî dinlerin ortak konusunu da irfânî perspektiften yorumlayarak dinlerin ortak düşünce mirasına katkıda bulunuyor. Mevlânâ’nın insanın iyi ve kötü amellerini cevher-araz kavramları üzerinden açılaması insanın eylemlerinin nihayetinde onun zatına dolayısıyla âyân-ı sabitesine ircâ olunacağını vurgulayan bir düşünme biçimini ortaya koymaktadır. Bu bakış açısı bir yandan mükellefiyetin sürdüğü ancak sebeblerin değil müsebbibin ve rahmetin öne çıtı̆̆ olan kulluk ilişkisinin salt insanın eylemleriyle sınırlanmadığı metafizik bir yorumlama biçimi olarak da görülebilir.

Mevlânâ ortak bazı sembolleri kullanırken ortak düşünce mirasını sûfi düşünceyle yeniden yorumlamakta nihayetinde kendi tasavvurunu ortaya koymaktadır. Mevlânâ başta olmak üzere sûfî düşüncede Hz. Âdem kendi iradesiyle hataya/zelleye düşmüş olup yine kendi iradesiyle tevbe ederek sorumluluğunu üstlenmiştir. Dolayısıyla günah Âdemoğulları ile Allah arasında kaldırılması gereken bir perdedir terk ve pişmanlıkla bu perde kaldırıldığında rahmet-i ilâhînin yeniden insanla buluşması umut edilir. İnsanın söz ve amellerinin gayret-i ilâhînin önünde akamete uğramasından sonraki pişmanlığı Mesnevî̀de kırılmış incinin parlaması mataforuyla ifade edilmektedir. Diğer yandan tasavvuf düşünce geleneğinde aslî günah kavramı yoktur, her insan kendi iradesinden ve fiillerinden sorumludur.

Mevlânâ Mesnevîye “dinle ney”den diye başlarken insana sadece aslî vatanını değil aynı zamanda insanoğlunun atası Âdem Peygamber'in cennetten dünyaya gönderilmesi bağlamında insana kendi gerçekliğini de hatırlatıyor. Gerçekte insan her dem günaha da tevbeye de hem çok uzak hem çok yakındır. İnsanoğlu mutlak sûrette hatadan ve günahtan âzâde değildir ancak günah kavramı tevbeyle birlikte ele alındığında 
Mevlânâ’nın düşünce sisteminde günahın belirleyici, insanı esir alan ve etken pozisyondan pasif ve edilgen bir pozisyona indirgendiği tevbenin ise asıl ve belirleyici bir pozisyona çekildiği görülmektedir.

Çıkar Çatışması / Conflict of Interest: Yazarlar çıkar çatışması olmadığını beyan etmiştir. / The authors declared that there is no conflict of interest.

Finansal Destek / Grant Support: Yazarlar bu çalışma için finansal destek almadıklarını beyan etmiştir. / The authors declared that this study has received no financial support.

\section{Kaynakça}

Ankaravî, İsmâil Rusûhî. Minhâcu’l Fukarâ. İstanbul: İnsan Yayınları, 2011.

Ankaravî, İsmâil Rusûhî. Şerh-i Mesnevî. İstanbul: Matba’a-'i 'Amire, 1872.

Augustinus. İstencin Özgür Tercihi Üzerine. çev. Metin Topuz. İstanbul: Say Yayınları, 2015.

Aydın, Fuat. Pavlus ve Din Anlayışının Yansımaları. İstanbul: Marmara Üniversitesi, Sosyal

Bilimler Enstitüsü, Doktora Tezi, 2000.

Aydın, Fuat. Pavlus Hristiyanlğına Giriş. Ankara: Eskiyeni Yayınları, 2011.

Aydın, Mehmet. Hristiyan Kaynaklara Göre Hristiyanlık. Ankara: Türkiye Diyanet Vakfı Yayınları, 3.baskı, 2007.

Aykıt, Dursun Ali. “Pelagianizm' in Tarihi ve Öğretileri”. İstanbul Üniversitesi İlahiyat Fakültesi Dergisi 22 (2010), 175-196.

Batuk, Cengiz. Hristiyanlğın Aslî Günah Doktrini Bağlamında Mitoloji ve Tarihsellik. Samsun: Ondokuz Mayıs Üniversitesi, Sosyal Bilimler Enstitüsü, Doktora Tezi, 2006.

Beydâvî Nasıruddîn Ebû Said Abdullah bin Ömer bin Muhammed eş- Şirâzî. Envâru't-Tenzîl ve Esrâru't-Te'vîl. Beyrut: Dâru'-r Reşîd, 1421.

Caka, Eduart. Bir Mistik Olarak Pavlus. Bursa: Uludağ Üniversitesi, Sosyal Bilimler Enstitüsü, Doktora Tezi, 2014.

Cengiz, Muammer. “Tasavvuf Tarihinde Elest Mîsâkına Dair Yorumlar”. Uluslararast Sosyal Araştırmalar Dergisi 10/50 (Haziran 2017), 904-924.

Çoban, Ali. Cezire-i Mesnevî ve Şerhlerine Göre Mevlevî Sülûku. Konya: Palet Yayınları, 2021.

Doğan, Bilal. Hristiyanlıkta Aslî Günah Doktrini. Bursa: Uludağ Üniversitesi Sosyal Bilimler Enstitüsü, Doktora Tezi, 2008.

Espensberger, Joh. Nep. Die Elemente der Erbsünde nach Augustinus und der Frühscholastik. ed. Albert Ehrhard - Johann Peter Kirsch. Mainz: Verlag von Kirchheim, 1905.

Gündüz, Şinasi. Hristiyanlık. İstanbul: İsam Yayınları, 2013.

Gündüz, Şinasi. Pavlus: Hristiyanlığın Mimarı. Ankara: Ankara Okulu, 2001.

Gündüz, Şinasi. “Pavlus Teolojisinde Gnostik Unsurlar”. Dini Araşttrmalar Dergisi 2/6 (2000). 


\section{Sufinge}

254

\section{Abdullah KUŞLU}

İbn Arabî. Âdem Kelimesindeki İlahi Hikmet Fassı. çev. Mehmed Ali Nusreddin. İstanbul: Litera Yayınları, 2016.

Kahraman, Ferruh. “Bir Tefsîr - Kelâm Problemi: Hz. Âdem’in Yasak Ağaca Yaklaşması”. Sakarya Üniversitesi İlahiyat Fakültesi Dergisi 15/27 (2013), 191-226.

Kahraman, Ferruh. Hristiyanlkk ve İslamiyette Günah. İstanbul: Rağbet Yayınları, 2011.

Katolik Kilisesi Din ve Ahlak İlkeleri, çev. Dominik Pamir (İstanbul: Yaylacık Matbaacılık Ltd. Şti., 2000).

Kur'an Yolu (Türkçe Meâlve Tefsir). çev. Hayrettin Karaman vd. Ankara: Diyanet İşleri Başkanlığı Yayınları, 2014.

Konuk, Ahmet Avni. Fusûsu'l-Hikem Tercüme ve Şerhi I. İstanbul: M. Ü. İlâhiyat Fakültesi Yayınları, 1999.

Konuk, Ahmet Avni. Mesnevîi-i Şerif Şerhi. İstanbul: Kitabevi Yayınları, 2008-2012.

Mevlânâ. Mesnevî-i Manevî. Konya: Konya Kültür A.Ş., 1384.

Şahin, Nadide. "Hristiyanlıkta ve İslam'da Kurtuluş Anlayışı”. Sosyal Bilimler Dergisi/The Journal of Social Science 5/29 (2018), 477-498.

Şemseddin, Sâmi. Kâmûs-ı Türkî. İstanbul: Dersaâdet Yayınları, 1317.

Tarakçı, Muhammet. “St. Thomas Aquinas’a Göre Aslî Günah”. Uludağ Üniversitesi İlahiyat Fakültesi Dergisi 15/1 (2006), 307-318.

Uğur, Hakan. Tevrat'ın Kur'an’a Arzı: Kur’an’ın Tevratta Tasdik Ettiği Konular. Bursa: Emin Yayınları, 2011.

Zebîdî. Tâcül'-'arûs. Kuveyt: Matbât-ü Hukûmet-il Kuveyt, 1407.

Zemahşerî, Ebu'l-Kâsım Cârullah Mahmûd b. Ömer b. Muhammed el-Harizmî. El-Keşşâf'anHakā'ikı Ġavâmizì't-Tenzîl ve 'uyûni'l-Ekâavîl fî-Vücûhi't-Te'vîl I. ed. Murat Sülün. çev. Muhammed Çoşkun vd. İstanbul: Türkiye Yazma Kurumlar Başkanlığı Yayınları, 2016. 